CLIMATOLOGICAL ATLAS OF CANADA.

Prepared by M. K. Thomas. Ottawa: Department of Transport, Meteorological Division, and National Research Council, Division of Building Research, 1953. (N.R.C. No. 3151; D.B.R. No. 41). $12 \times 9$ inches; 256 pages; charts, tables, and graphs. $\$ 2.00$.

Climate is one of the most important influences on building in any country. When it was necessary to revise the National Building Code of Canada, first published in 1941, a section dealing with climate was planned. As the work developed it was seen that many more charts would be useful than could possibly be included in the National Building Code. The 'Climatological atlas of Canada' is a joint undertaking of the Meteorological Division, Department of Transport and the Division of Building Research, National Research Council; it was prepared by $M$. K. Thomas, of the Canadian Meteorological Service, who has been working with the Division of Building Research. The atlas contains not only the twelve charts included in the revised code, but also all the other charts prepared in this basic study of Canadian climate in relation to building problems. The atlas gives a broad coverage of climatic variations throughout Canada, and is useful in fields other than building. Isopleths for most of the climatic elements have been carried into the Arctic.

The eighty-two charts and tables are grouped into nine sections, under the usual climatic headings, plus sunshine and insolation, seismological disturbances, and permafrost. Short, well-edited explanatory notes precede each section of charts, and similar texts accompany each chart. The layout is well planned, and it is a pleasure to be able to read the note and study the chart without having to turn the page.

In the section on temperature it is interesting to find, apart from the standard definitions, a series of charts showing winter design temperature, "the coldest temperature which is likely to recur frequently enough during the average winter to justify its use in the design of heating systems for structures". Similarly, summer design temperature charts, dealing with heat instead of cold, give an unusual picture of temperature conditions throughout the country. A beautiful illustration of temperature conditions in Canada is given in Chart No. 1-22, "Mean annual total degree-days". A degree-day is a unit based upon temperature difference and time. It is used by fuel-oil companies in estimating fuel consumption. In Canada the increase in the number of degree-days from south to north is quite marked, showing the combination of the severity and the duration of the winter season in the different latitudes. Other charts show the extreme lowest recorded temperature and the mean of the lowest temperature each year, over a number of years. These charts reveal that the northern parts of the Prairie Provinces, Yukon Territory, and central Quebec have mean annual minimum temperatures as low as arctic Canada, and that the absolute lowest temperatures recorded in many settled parts of the country are as low as those in the Arctic. However, the time element is not considered in these records, as it is in the degree-day chart, where winter, as a combination of low temperature and long duration, is clearly demonstrated to be dependent on latitude and distance from the sea.

The section on wind is also well planned and instructive, especially the unusual "Computed maximum gust speed" charts. The only additional information one could wish for is some indication of windchill. Charts showing the combination of wind speeds with air temperatures throughout the country at the various seasons would have helped to illustrate the cooling, which, in certain regions, affects human beings and mechanical equipment intensely.

The atlas is really more than a 'Climatological atlas'. It contains a table showing the total possible duration of sunlight on the 15th of each month for latitudes $40^{\circ} \mathrm{N}$. to $85^{\circ} \mathrm{N}$.; it has a series of tables showing the altitude of the sun 
at various times of day on the 21 st of each month for different latitudes; it includes a very interesting chart of earthquake probability, and a section showing hythergraphs. Hythergraphs are diagrams, devised by Dr. Griffith Taylor, to show in a twelve-sided figure the mean precipitation and mean temperature of a chosen location for each month of the year. The atlas contains hythergraphs for the largest cities of the country and for representative locations in northern Canada; hythergraphs for London, Paris, and $\mathbf{W}$ ashington have been included for comparison. In Dr.
Taylor's 'Canada' there is a "comfort frame" showing the values of temperature and precipitation for a place with a "comfortable climate", (comfortable for people of middle latitudes; tropical peoples and Eskimo have different standards). It would have been interesting to see this "comfort frame" included in the atlas for it would emphasize how far most of Canada's climate is from "comfortable".

The atlas is a beautiful production at a surprisingly low price and deserves to be widely used.

Svenn Orvig

\section{ELECTION OF FELLOWS}

At the Annual Meeting of the Arcric Institute held in Montreal on 20 November 1954 the following were elected Fellows of the Institute:

Dr. Colin Bertram, Scott Polar Research Institute, Lensfield Road, Cambridge, England.

Prof. J. B. Bird, Department of Geography, McGill University, Montreal, Que., Canada.

Dr. Charles E. Bunnell, College, Alaska.

Col. N. A. C. Croft, Scott Polar Research Institute, Lensfield Road, Cambridge, England.

Dr. Christian T. Elvey, Geophysical Institute, College, Alaska.

Gerald FitzGerald, U.S. Department of the Interior, Washington 25, D.C., U.S.A.

Col. J. O. Fletcher, U.S.A.F., Air University, Montgomery, Ala., U.S.A.

Dr. George O. Gates, U.S. Department of the Interior, 4 Homewood Place, Menlo Park, Calif., U.S.A.

Dr. E. H. Grainger, 3485 University Street, Montreal, Que., Canada.

T. A. Harwood, Arctic Section, Defence Research Board, Ottawa, Ont., Canada.

Dr. William S. Laughlin, University of Oregon, Eugene, Ore., U.S.A.
Dr. E. N. Patty, University of Alaska, College, Alaska.

Dr. L. O. Quam, Geography Branch, Office of Naval Research, 990 North Tuckahoe St., Falls Church, Va., U.S.A.

G. W. Rathjens, P.O. Box 317, Berkeley, Calif., U.S.A.

Dr. Brian Roberts, Scott Polar Research Institute, Lensfield Road, Cambridge, England.

Mrs. Diana Rowley, 10 Maple Lane, Ottawa, Ont., Canada.

Dr. Ivar Skarland, University of Alaska, College, Alaska.

Dr. William C. Steere, Stanford University, Stanford, Calif., U.S.A.

Andrew Thomson, Meteorological Division, Department of Transport, 315 Bloor St. W., Toronto, Ont., Canada.

Dr. R. C. Wallace, 4 Centre St., Kingston, Ont., Canada.

Prof. Mogens Westergaard, Universitetets Genetiske Institut, Universitetsparken 3, Copenhagen, Denmark.

Dr. I. L. Wiggins, Department of Biology, Stanford University, Stanford, Calif., U.S.A. 